\title{
Optimization of phosphorus content in high plant protein practical diets for Senegalese sole (Solea senegalensis, Kaup 1858) juveniles: influence on growth performance and composition of whole body and vertebrae
}

\author{
E. SALAS-LEITON ${ }^{1}$, J. DIAS ${ }^{2}$, P. GAVAIA ${ }^{3}$, A. AMOEDO ${ }^{1}$ \& L.M.P. VALENTE ${ }^{1}$ \\ ${ }^{1}$ CIIMAR/CIMAR L.A., Centro Interdisciplinar de Investigação Marinha e Ambiental and ICBAS, Instituto de Ciências \\ Biomédicas de Abel Salazar, Universidade de Porto, Porto, Portugal; ${ }^{2}$ SPAROS Lda, Olhão, Portugal; ${ }^{3}$ CCMAR/ \\ CIMAR L.A., Centro de Ciências do Mar, University of Algarve, Faro, Portugal
}

\begin{abstract}
Practical diets containing PP sources were elaborated. Increasing levels of di-calcium phosphate were added to diets leading to five different dietary available P levels: 2.5, $3.2,6.0,6.5$ and $8.0 \mathrm{~g} \mathrm{~kg}^{-1}$ dry diet. The dietary treatments were tested in $13.5 \mathrm{~g}$ Senegalese sole juveniles throughout an 82-day experimental period. Dietary $\mathrm{P}$ content had no effect on the productive parameters, while nutrient intake was also similar among dietary treatments, except $\mathrm{P}$ intake. Dry matter ADC ranged between $54.9 \%$ and $64.0 \%$, and the highest $\mathrm{P}$ ADCs value $(47.2 \pm 0.7 \%)$ was achieved in fish fed AP6.0. Dietary phosphorus level significantly influenced body lipid and $\mathrm{P}$ compositions. Regression analysis performed on whole-body $\mathrm{P}$ and ash contents fitted to quadratic models. Vertebral bone $\mathrm{P}$ content was low but increased significantly with increasing dietary $\mathrm{P}$ levels. Bone density and deformities occurrence were, however, similar between experimental conditions. An altered status of bone formation-resorption processes in soles fed the lowest $\mathrm{P}$ content diet might be inferred from ALP and TRAP activities. In conclusion, overall results state a high tolerance of Senegalese sole to low $\mathrm{P}$ content diets and support the utilization of practical diets with high plant protein content.
\end{abstract}

KEY WORDS: bone mineralization, digestibility, flatfish, growth, phosphorus requirement, plant protein

Received 12 January 2015; accepted 29 June 2015

Correspondence: Luisa María Pinheiro Valente, CIIMAR - Centro Interdisciplinar de Investigação Marinha e Ambiental, Instituto de Ciências Biomédicas de Abel Salazar, Universidade de Porto, Rua dos Bragas, 289,4050-123 Porto,Portugal.E-mail: lvalente@icbas.up.pt

\section{Introduction}

Phosphorus (P) is an essential mineral element in aquafeeds and a major structural constituent of fish skeletal tissues (e.g. bone and scales) in the form of hydroxyapatite (Lall \& Lewis-McCrea 2007). Phosphorus is also a key part of relevant organic molecules such as phospholipids, coenzymes, nucleic acids and energy-rich compounds playing key roles in intermediate metabolism functions (Kaushik 2001; Lall 2002; NRC 2011). Fishmeal (FM) is the main source of $P$ in aquafeeds (Lall 2002), and it still remains the major dietary protein source for carnivorous fish species (Tacon \& Metian 2008). Considering the limited FM availability and the tendency towards sustainable aquaculture practices, new nutritional strategies need to be adopted to maintain the global development of the industry, with a reported annual growth rate of $8-9 \%$ in last 40 years (FAO, 2011). Considerable research efforts were made to search for alternative protein sources, and plant protein (PP) has been increasingly used to substitute FM in aquafeeds (Kaushik et al. 2004; Dias et al. 2009; Pratoomyot et al. 2010; Lund et al. 2011; Cabral et al. 2013). However, when high PP levels are considered in the formulation, special caution must be taken to avoid dietary $\mathrm{P}$ deficiency. The phytate molecule (salt of myo-inositol-hexaphosphate) is the major form of $\mathrm{P}$ storage (up to $80 \%$ ) in plant ingredients such as barley, rice, sorghum, wheat, corn, rapeseed, soybean, cottonseed and sunflower. But phytase, the enzyme responsible to release orthophosphate from phytate in the gastrointestinal tract, generally has a low endogenous activity in fish (reviewed in Gatlin et al. 2007). The optimization of dietary $P$ content by the addi- 
tion of exogenous $\mathrm{P}$ sources becomes an important nutritional issue when diets with high PP contents are chosen to feed farmed fish species.

Dietary $\mathrm{P}$ deficiency has been associated with a wide variety of effects in cultivated fish (Sugiura et al. 2004). Reduction in productive parameters and poor bone mineralization - evaluated through vertebral $\mathrm{P}$ level - have been widely reported in pelagic species juveniles fed deficient dietary $\mathrm{P}$ contents (reviewed in Prabhu et al. 2013). Other relevant consequences associated with such deficiency conditions are decreased voluntary feed intake (VFI) and body lipid accumulation, as reported in aquaculture produced species as gilthead sea bream (Sparus aurata) (Pimentel-Rodrigues \& Oliva-Teles 2001), black sea bream (Sparus macrocephalus) (Shao et al. 2008), Japanese sea bass (Lateolabrax japonicus) (Zhang et al. 2006), haddock (Melanogrammus aeglefinus) (Roy \& Lall 2003), large yellow croaker (Pseudosciaena crocea) (Mai et al. 2006) and rainbow trout (Oncorhynchus mykiss) (Rodehutscord et al. 1995). Based on such response criteria, an overall range of 3-9 $\mathrm{g}$ available $\mathrm{P} \mathrm{kg}^{-1}$ diet may be thus considered as optimum dietary content for most pelagic species (reviewed in Prabhu et al. 2013). There is limited information concerning flatfish $\mathrm{P}$ requirement, but reduced bone mineralization and increased vertebral abnormalities were reported in Atlantic halibut (Hippoglossus hippoglossus) (Lewis-McCrea \& Lall 2010), whereas decreased growth was observed in Japanese flounder (Paralichthys olivaceus) (Wang et al. 2005) fed dietary total $\mathrm{P}$ content below $4-5 \mathrm{~g} \mathrm{~kg}^{-1}$ diet. Decreased feed intake and altered $\mathrm{P}$, lipid and ash body composition were also observed in Japanese flounders fed total dietary $\mathrm{P}$ content of $6-8 \mathrm{~g} \mathrm{~kg}^{-1}$ diet (Uyan et al. 2007). However, these studies in flatfish refer to total $\mathrm{P}$ rather than available $\mathrm{P}$. The apparent digestibility coefficients (ADCs) of $\mathrm{P}$ show a wide variation (from 20 to $90 \%$ ) between species and dietary formulations (Åsgård \& Shearer 1997; Kim et al. 1998; Mai et al. 2006; Zhang et al. 2006; Cabral et al. 2011), strongly influencing available $\mathrm{P}$ to fish. As an example, ADC of $\mathrm{P}$ in Atlantic salmon (Salmo salar) decreased from $89 \%$ to $64 \%$ when canola meal was used instead casein as main dietary ingredient (Åsgård \& Shearer 1997; Sajjadi \& Carter 2004). A total dietary $\mathrm{P}$ content ensuring a minimum available $\mathrm{P}$ fraction is thus required for all fish species, being highly recommended a specific assessment of $\mathrm{P}$ deficiency signs caused by potentially inadequate dietary conditions.
Senegalese sole is a flatfish of high commercial value and a candidate to diversify the southern Europe aquaculture (Morais et al. 2014). Recent results demonstrated an extremely positive response in terms of growth, feed intake and nutrient utilization of this species to practical diets containing high levels of plant protein sources (Silva et al. 2009, 2010; Cabral et al. 2011, 2013; Valente et al. 2011). However, the dietary $P$ requirement in Senegalese sole has never been determined. In this study, experimental diets were formulated using practical ingredients and contained high levels of plant protein sources to assure minimal $\mathrm{P}$ availability (2.5 $\mathrm{g}$ available $\mathrm{P} \mathrm{kg}^{-1}$ dry diet) to fish. The effect of dietary available $\mathrm{P}$ level (increasing from 2.5 to $8.0 \mathrm{~g} \mathrm{~kg}^{-1}$ dry diet) was evaluated in Senegalese sole juveniles. After 82 days, growth performance, nutrient utilization and body composition were evaluated. Vertebrae $\mathrm{P}$ content, bone density and deformities incidence were also assessed. The activities of alkaline phosphatase (ALP) and tartrate-resistant acid phoshatase (TRAP) were also determined and related to bone mineralization.

\section{Material and methods}

The experimental procedures were performed by trained scientists (following category C FELASA recommendations) and conducted according to the European guidelines on protection of animals used for scientific purposes (directive 2010/63/UE of European Parliament and of the Council of European Union).

\section{Experimental diets}

The trial comprised five isonitrogenous $\left(550 \mathrm{~g} \mathrm{~kg}^{-1}\right.$ dry matter, DM), isolipidic ( $\left.90 \mathrm{~g} \mathrm{~kg}^{-1} \mathrm{DM}\right)$ and isoenergetic $\left(21 \mathrm{~kJ} \mathrm{~g}^{-1} \mathrm{DM}\right)$ diets. Details on formulation, proximate composition and mineral levels are presented in Table 1. All diets were formulated with the same practical ingredients and contained high levels of PP sources (basically a blend of soybean meal, corn gluten, wheat gluten, peas and potato concentrate) to assure minimal $\mathrm{P}$ levels available to fish. Marine-derived protein sources (fishmeal, squid meal and fish soluble protein concentrate) represented $15 \%$ of the formula and accounted for $24 \%$ of the total crude protein supply. The dietary fat level was set at $90 \mathrm{~g} \mathrm{~kg}^{-1} \mathrm{DM}$ in accordance with recommendations for this species (Borges et al. 2009). All diets were supplemented with crystalline indispensable amino acids 
Table 1 Ingredients, proximate composition and mineral levels of the experimental diets

\begin{tabular}{|c|c|c|c|c|c|}
\hline & \multicolumn{5}{|c|}{ Dietary treatments } \\
\hline & AP2.5 & AP3.2 & AP6.0 & AP6.5 & AP8.0 \\
\hline \multicolumn{6}{|l|}{ Feed ingredients ( $\mathrm{g} \mathrm{kg}^{-1}$ dry diet) } \\
\hline Fishmeal $70 \mathrm{LT}^{1}$ & 55 & 55 & 55 & 55 & 55 \\
\hline Fish soluble protein concentrate ${ }^{2}$ & 50 & 50 & 50 & 50 & 50 \\
\hline Squid meal ${ }^{3}$ & 50 & 50 & 50 & 50 & 50 \\
\hline Pea protein concentrate ${ }^{4}$ & 140 & 140 & 140 & 140 & 140 \\
\hline Wheat gluten ${ }^{5}$ & 70 & 72 & 74 & 74 & 77 \\
\hline Potato protein concentrate ${ }^{6}$ & 60 & 60 & 60 & 60 & 60 \\
\hline Corn gluten ${ }^{7}$ & 90 & 90 & 90 & 90 & 90 \\
\hline Soy protein concentrate ${ }^{8}$ & 47 & 47 & 47 & 47 & 47 \\
\hline Solvent extracted soybean meal ${ }^{9}$ & 98 & 98 & 98 & 98 & 98 \\
\hline Dehulled pea grits ${ }^{10}$ & 125 & 125 & 125 & 125 & 125 \\
\hline Whole wheat & 128 & 111 & 94 & 79 & 61 \\
\hline Fish oil $^{11}$ & 60 & 60 & 60 & 60 & 60 \\
\hline Vitamin and mineral premix ${ }^{12}$ & 10 & 10 & 10 & 10 & 10 \\
\hline Guar gum & 10 & 10 & 10 & 10 & 10 \\
\hline Di-calcium phosphate ${ }^{13}$ & 0 & 15 & 30 & 45 & 60 \\
\hline L-lysine & 5 & 5 & 5 & 5 & 5 \\
\hline DL-methionine & 2 & 2 & 2 & 2 & 2 \\
\hline \multicolumn{6}{|c|}{ Proximate composition ( $\mathrm{g} \mathrm{kg}^{-1}$ dry diet) } \\
\hline Dry matter & 951.6 & 954.2 & 924.5 & 924.7 & 945.2 \\
\hline Ash & 46.5 & 57.6 & 73.6 & 85.9 & 96.1 \\
\hline Crude protein & 561.2 & 554.9 & 562.0 & 545.9 & 560.7 \\
\hline Crude fat & 96.4 & 91.3 & 87.7 & 85.5 & 83.7 \\
\hline Gross energy (kJ g $\left.{ }^{-1} \mathrm{DM}\right)$ & 22.04 & 21.86 & 21.35 & 21.29 & 21.21 \\
\hline \multicolumn{6}{|l|}{ Dietary mineral level ( $\mathrm{g} \mathrm{kg}^{-1}$ dry diet) } \\
\hline Total phosphorus & 6.51 & 8.83 & 12.73 & 14.63 & 17.73 \\
\hline Non-phytic phosphorus ${ }^{14}$ & 4.60 & 7.17 & 10.96 & 12.42 & 15.85 \\
\hline Available phosphorus ${ }^{15}$ & 2.52 & 3.21 & 6.01 & 6.47 & 8.03 \\
\hline Total calcium & 3.61 & 6.15 & 6.68 & 8.70 & 10.50 \\
\hline Total P/total Ca & 1.80 & 1.44 & 1.90 & 1.68 & 1.69 \\
\hline
\end{tabular}

${ }^{1}$ Peruvian fishmeal 70 LT: 71\% crude protein (CP), 8\% crude fat (CF), EXALMAR, Peru.

${ }^{2}$ CPSP 90: $84 \%$ CP, $12 \%$ CF, Sopropêche, France.

${ }^{3}$ Super Prime squid meal: $80 \% \mathrm{CP}, 3.5 \% \mathrm{CF}$, Sopropêche, France.

${ }^{4}$ Lysamine GP: $78 \% \mathrm{CP}, 8 \% \mathrm{CF}$, ROQUETTE, France.

${ }^{5}$ VITEN: $85.7 \%$ CP, $1.3 \%$ CF, ROQUETTE, France.

${ }^{6}$ Tubermine GP: $78 \%$ CP, $1.5 \%$ CF, ROQUETTE, France.

${ }^{7}$ Corn gluten feed: $61 \% \mathrm{CP}, 6 \% \mathrm{CF}$, COPAM, Portugal.

${ }^{8}$ Soycomil P: $65 \%$ CP, $0.8 \% \mathrm{CF}, \mathrm{ADM}$, The Netherlands.

${ }^{9}$ Solvent extracted dehulled soybean meal: $47 \% \mathrm{CP}, 2.6 \% \mathrm{CF}$, SORGAL SA, Portugal.

${ }^{10}$ Aquatex G2000: $24 \%$ CP, $0.4 \%$ CF, SOTEXPRO, France.

11 COPPENS International, The Netherlands.

12 PVO40.01 Premix for marine fish, PREMIX Lda, Portugal. Vitamins (IU or $\mathrm{mg} \mathrm{kg}^{-1}$ diet): DL-alpha tocopherol acetate, $100 \mathrm{mg}$; sodium menadione bisulphate, $25 \mathrm{mg}$; retinyl acetate, $20000 \mathrm{IU}$; DL-cholecalciferol, $2000 \mathrm{IU}$; thiamin, $30 \mathrm{mg}$; riboflavin, $30 \mathrm{mg}$; pyridoxine, $20 \mathrm{mg}$; B12, $0.1 \mathrm{mg}$; nicotinic acid, $200 \mathrm{mg}$; folic acid, $15 \mathrm{mg}$; ascorbic acid, $1000 \mathrm{mg}$; inositol, $500 \mathrm{mg}$; biotin, $3 \mathrm{mg}$; calcium panthotenate, $100 \mathrm{mg}$; choline chloride, $1000 \mathrm{mg}$, betaine, $500 \mathrm{mg}$. Minerals ( $\mathrm{g}$ or $\mathrm{mg} \mathrm{kg}^{-1}$ diet): cobalt sulphate, $2.5 \mathrm{mg}$; copper sulphate, $1.1 \mathrm{mg}$; ferric citrate, $0.2 \mathrm{~g}$; potassium iodide, $5 \mathrm{mg}$; manganese sulphate, $15 \mathrm{mg}$; sodium selenite, $0.2 \mathrm{mg}$; zinc sulphate, $40 \mathrm{mg}$; magnesium hydroxide, $0.6 \mathrm{~g}$; potassium chloride $1.1 \mathrm{~g}$; sodium chloride, $0.5 \mathrm{~g}$; calcium carbonate, $4 \mathrm{~g}$.

${ }^{13}$ Di-calcium phosphate: $18 \%$ phosphorus, $23 \%$ calcium, Fosfitalia, Italy.

${ }^{14}$ Calculated as: Total $\mathrm{P}$ - Bound to phytic acid P.

${ }^{15}$ Individually calculated values for every dietary condition by digestibility assay with $\mathrm{Cr}_{2} \mathrm{O}_{3}$.

(L-lysine and DL-methionine) to meet the species requirements. Five increasing levels of di-calcium phosphate (DCP) were added to diets: $0,15,30,45$ and $60 \mathrm{~g} \mathrm{~kg}^{-1}$ $\mathrm{DM}$, and the experimental diets were named following their respective available phosphorus (AP) contents: AP2.5, AP3.2, AP6.0, AP6.5 and AP8.0. Di-calcium phosphate was incorporated at the expenses of wheat meal and wheat gluten. 
All ingredients were finely grounded (hammer mill, $0.2 \mathrm{~mm}$ sieve), mixed and then extruded (twin screw extruder, $2.0 \mathrm{~mm}$ pellet size, SPAROS, Portugal). Diets were finally dried at $45{ }^{\circ} \mathrm{C}$ for $12 \mathrm{~h}$ and stored at $4{ }^{\circ} \mathrm{C}$ until use.

The digestibility trial was carried out with the same experimental diets but supplemented with $1 \%$ chromic oxide $\left(\mathrm{Cr}_{2} \mathrm{O}_{3}\right)$ as an inert marker.

\section{Fish and rearing conditions}

The growth trial was conducted at the experimental facilities of CIIMAR, Porto, Portugal. Senegalese sole juveniles were supplied by a commercial fish farm (Coelho \& Castro, Lda, Póvoa do Varzim, Portugal. After arrival at the experimental unit, fish were kept under quarantine conditions for a 2-week period. Once they were acclimated to the new rearing facilities, triplicate groups of 23 fish $(13.5 \pm 1.9 \mathrm{~g})$ per dietary condition were individually weighed, measured and distributed (initial stocking density of $1.5 \mathrm{~kg} \mathrm{~m}^{-2}$ ) among 15 fibreglass rectangular tanks $(0.5 \times 0.4 \mathrm{~m})$ in a closed recirculation system. The system was supplied with filtered and heated $\left(20.0 \pm 1.0^{\circ} \mathrm{C}\right)$ saltwater $\left(24 \%\right.$ and a flow rate of $\left.1.5 \mathrm{~L} \mathrm{~min}^{-1}\right)$. Total ammonium, nitrite, nitrate and $\mathrm{pH}$ levels were measured during the entire trial to ensure levels within the recommended ranges for marine species. Dissolved oxygen level was kept above $90.0 \% \pm 1.0$ saturation. An artificial photoperiod of 12-h light:12-h dark was established. Fish were fed ad libitum using automatic feeders that distributed 6 to 10 meals day ${ }^{-1}$ during 82 days. The meal size offered to each tank was daily adjusted according to daily observations by an experienced researcher and based on the presence/absence of uneaten feed in each tank (Borges et al. 2009; Cabral et al. 2013).

By the end of the feeding trial and after 24-h fasting period, fish were individually weighed $(\mathrm{g})$ and measured (total length, $\mathrm{cm}$ ). Ten fish from the initial stock and four fish from each tank at the end of the trial were sacrificed and stored at $-20{ }^{\circ} \mathrm{C}$ for subsequent determination of wholebody composition. The vertebral columns (free of soft tissue) of 4 fish per tank were also collected and kept at $-80{ }^{\circ} \mathrm{C}$ until subsequent $\mathrm{X}$-ray analysis for bone density and deformities, determination of vertebrae $\mathrm{P}$ content and activity of bone metabolic enzymes. In all cases, a dose of $100 \mathrm{mg} \mathrm{L}^{-1}$ MS-222 was used as anaesthetic before fish sacrifice by decapitation and tissue collection.

After the feeding trial, the remaining fish of each treatment were distributed by 2 tanks to determine the ADC of experimental diets using $1 \%$ chromic oxide as a dietary inert tracer (Maynard et al. 1979). The traditional non-invasive method for collecting faeces could not be used due to aqueous consistency of Senegalese sole faeces. Previously reported methodology in this species was thus followed (Cabral et al. 2011, 2013; Borges et al. 2013). Fish were fed twice a day during 1 week to achieve the complete evacuation of previous meals. Following a 24-h starvation period, fish were fed one last single meal, in excess. Between 8 and $10 \mathrm{~h}$ after such meal, the time required for digesta to reach the posterior intestine (Dias et al. 2010), fish were sacrificed by a sharp blow on the head and dissected. The content of their posterior intestines (from the ileocaecal valve to the anus) was carefully collected. Faeces samples from fish stocked in each tank were pooled, generating duplicates for each dietary condition. Pooled faeces were frozen at $-20{ }^{\circ} \mathrm{C}$ prior to analysis.

\section{Analytical methods}

Whole fish from each tank were ground, pooled and the moisture content determined $\left(105^{\circ} \mathrm{C}\right.$ for $\left.24 \mathrm{~h}\right)$. Samples were subsequently lyophilized before further analysis. Both feed and whole-body analysis were carried out in duplicate following the methodology described by AOAC (2006). Ash was analysed by combustion $\left(550{ }^{\circ} \mathrm{C}\right.$ during $\left.6 \mathrm{~h}\right)$ in a muffle furnace (Nabertherm L9/11/B170, Bremen, Germany) and crude protein $(\mathrm{N} \times 6.25)$ using a Leco $\mathrm{N}$ analyser (Model FP-528; Leco Corporation, St. Joseph, MI, USA). Crude lipid content was determined by petroleum ether extraction $\left(40-60{ }^{\circ} \mathrm{C}\right)$ using a Soxtec ${ }^{\mathrm{TM}} 2055$ Fat Extraction System (Foss, Hilleroed, Denmark) and gross energy in an adiabatic bomb calorimeter (Werke C2000 basic; IKA, Staufen, Germany).

Total P content in feed, whole body and vertebrae samples was determined by spectrophotometry $(820 \mathrm{~nm})$ after mineralization and acid digestion, following the molybdateblue/ascorbic acid method (Murphy \& Riley 1962). The phytic acid content in feed was colorimetrically determined using free iron ion and sulphosalicylic acid, according to SAA A 006 method by ÖHMI Analytik GmbH (Magdeburg, Germany). An average P content of $28.2 \%$ in phytate molecule was considered. Total calcium content in feed was determined after microwave digestion procedure using an aqueous solution of $\mathrm{HNO}_{3}$ (Reis \& Almeida 2008). Chromium oxide quantification in feed and faecal samples was performed by digestion (perchloric acid) and colorimetric method (Bolin et al. 1952).

Bone density and deformities occurrence in axial skeleton were determined by X-ray scanning. X-ray images were 
obtained with a small animal digital X-ray apparatus Kodak DSX 4000 PRO (Carestream, Rochester, NY, USA). Fish were exposed at $35 \mathrm{kVa}$ for $1 \mathrm{~min}$ and the digital image processed with the Carestream integrated analysis software. Density of vertebral bone in fish fed the experimental treatments was calculated according to Liu et al. (2013), considering the mean grey value as a value of integrated optical intensity (IOD). The analysis of bone deformities was focused on eight body regions including cranial skeleton and the unpaired anal, caudal and dorsal fins. The vertebral column was divided into 4 regions according to the morphological characteristics of the vertebrae: cephalic ( $\mathrm{v} 1-4)$, prehaemal ( $\mathrm{v}$ 5-9), haemal ( $\mathrm{v}$ 10-42) and caudal fin vertebrae (43-45, including urostile) as previously defined by Dionísio et al. (2012). The analysis of skeletal deformities evaluated both the incidence of deformities in each experimental group and the charge of such deformities per fish (CD, total deformities in each replicate*total number of fish analysed ${ }^{-1}$ ).

Prior to enzyme activities determination, vertebral bone samples were pulverized under liquid nitrogen, homogenized in a $0.1 \%$ Triton X-100 solution and centrifuged at $16000 \mathrm{~g}$ for $2 \mathrm{~min}$. Supernatants were used for bone ALP determination with p-nitrophenylphosphate as substrate according to Bessey et al. (1946) and bone TRAP using pnitrophenol phosphate as substrate (Goto \& Tsukamoto 2003). Protein was determined by the Bradford method (Bradford 1976) using bovine serum albumin as standard.

\section{Parameters and calculations considered in growth trial}

Daily growth index (DGI) was calculated as follows: 100* $\left[\left(W_{1}\right)^{1 / 3}-\left(W_{0}\right)^{1 / 3}\right]^{*}(\text { days })^{-1}$, where $W_{0}$ and $W_{1}$ are the initial and the final fish mean weight ( $\mathrm{g}$ ) of the fish. Feed conversion ratio (FCR) was calculated as the amount of dry feed intake $(\mathrm{g})^{*}$ weight gain $^{-1}(\mathrm{~g})$ and protein efficiency ratio (PER) as the weight gain $(\mathrm{g}) *$ ingested crude protein ${ }^{-1}$ (g). Voluntary feed intake (g or $\mathrm{kJ} \mathrm{kg}^{-1} \mathrm{ABW}$ day ${ }^{-1}$ ) was calculated as follows: cumulative feed consumption*average body weight $(\mathrm{ABW})^{-1}$ days $^{-1}$, where ABW (kg) was $\left(W_{1}+W_{0}\right) / 2$. The dry matter and $\mathrm{P}$ gain $\left(\mathrm{g} \mathrm{kg}^{-1}\right.$ ABW day $^{-1}$ ) were calculated as follows: (final carcass dry matter or $\mathrm{P}$ content - initial carcass dry matter or $\mathrm{P}$ content $) * \mathrm{ABW}^{-1} *$ days $^{-1}$. The retention ( $\%$ intake) was calculated as follows: $100 *\left(W_{1} *\right.$ final carcass dry matter or $\mathrm{P}$ content $-W_{0} *$ initial carcass dry matter or $\mathrm{P}$ content $) *$ total dry matter or $\mathrm{P}$ intake ${ }^{-1}\left(\mathrm{~g} \mathrm{~kg}^{-1} \mathrm{ABW} \mathrm{day}^{-1}\right)$.
The ADC of dry matter in the tested diets was calculated according to Maynard et al. (1979):

$\mathrm{ADC}_{\mathrm{DM}}=100 *\left[1-\left(D_{\mathrm{Cr}} * F_{\mathrm{Cr}}^{-1}\right)\right]$

where $\mathrm{ADC}_{\mathrm{DM}}=$ dry matter $\mathrm{ADC}(\%) ; D_{\mathrm{Cr}}=$ dietary $\mathrm{Cr}_{2} \mathrm{O}_{3}$ content $(\%) ; F_{\mathrm{Cr}}=$ faeces $\mathrm{Cr}_{2} \mathrm{O}_{3}$ content $(\%)$.

The ADC of $\mathrm{P}$ in the tested diets was calculated according to the following formula:

$\mathrm{ADC}_{\mathrm{P}}=1-\left[\left(D_{\mathrm{Cr}} * F_{\mathrm{Cr}}^{-1}\right) *\left(F_{\mathrm{P}} * D_{P}^{-1}\right)\right] * 100$

where $\quad \mathrm{ADC}_{\mathrm{P}}=$ phosphorus $\mathrm{ADC}(\%) ; \quad D_{\mathrm{Cr}}=$ dietary $\mathrm{Cr}_{2} \mathrm{O}_{3}$ content $(\%) ; F_{\mathrm{Cr}}=$ content of $\mathrm{Cr}_{2} \mathrm{O}_{3}$ in faeces $(\%)$; $F_{\mathrm{P}}=$ phosphorus content in faeces $(\%) ; D_{\mathrm{P}}=$ dietary phosphorus content $(\%)$.

The available $\mathrm{P}$ content $\left(\mathrm{g} \mathrm{kg}^{-1}\right.$ dry diet) in experimental diets was calculated as follows: dietary total $\mathrm{P}$ content $\left(\mathrm{g} \mathrm{kg}^{-1}\right.$ dry diet)*dietary ADC of P $(\%)$.

\section{Statistical analysis}

Statistical analyses followed the methods outlined by Zar (1999). All data were checked for normality (Shapiro-Wilk test) and homogeneity of variances (Levene's test) $(P>0.05)$. Dietary conditions with increasing $\mathrm{P}$ contents AP2.5, AP3.2, AP6.0, AP6.5 and AP8.0 - were submitted to one-way ANOVA. Individual means were compared using Tukey's and least significant difference Fisher's post hoc tests. When data did not meet the ANOvA assumptions, the Kruskal-Wallis nonparametric test was chosen instead. Significant differences were considered when $P<0.05$. Wholebody $\mathrm{P}$, whole-body ash and vertebrae $\mathrm{P}$ contents were correlated with the available $\mathrm{P}$ fraction contained in AP2.5, AP3.2, AP6.0, AP6.5 and AP8.0 diets. Best regression model was chosen according to $R^{2}$ value and simplicity. Statistical analyses used the IBM sPss Statistics 21 (IBM Corp., Armonk, NY, USA) software.

\section{Results}

\section{Growth performance}

Fish mortality was $\leq 1 \%$ in all experimental treatments. All groups exhibited at least a 2.5 -fold increase in their initial body weights (13.4-13.6 g) after the 12-week experimental period. No significant differences could be observed among dietary treatments (Table 2); AP3.2 and AP8.0 groups pre- 
Table 2 Growth performance and feed utilization $(n=3)$ of Senegalese sole fed the experimental period for 82 days

\begin{tabular}{|c|c|c|c|c|c|c|c|c|c|c|}
\hline \multirow[b]{3}{*}{ Growth } & \multicolumn{10}{|c|}{ Dietary treatments } \\
\hline & \multicolumn{2}{|l|}{ AP2.5 } & \multicolumn{2}{|l|}{ AP3.2 } & \multicolumn{2}{|l|}{ AP6.0 } & \multicolumn{2}{|l|}{ AP6.5 } & \multicolumn{2}{|l|}{ AP8.0 } \\
\hline & Mean & SD & Mean & SD & Mean & SD & Mean & SD & Mean & SD \\
\hline Initial body weight (g) & 13.56 & 0.15 & 13.38 & 0.37 & 13.53 & 0.07 & 13.50 & 0.03 & 13.52 & 0.02 \\
\hline Final body weight (g) & 31.87 & 1.40 & 30.71 & 3.26 & 32.13 & 0.07 & 30.78 & 0.03 & 33.12 & 1.40 \\
\hline DGI & 0.96 & 0.07 & 0.92 & 0.11 & 0.97 & 0.02 & 0.92 & 0.10 & 1.01 & 0.06 \\
\hline FCR & 1.11 & 0.05 & 1.17 & 0.04 & 1.12 & 0.06 & 1.24 & 0.08 & 1.14 & 0.06 \\
\hline PER & 1.60 & 0.07 & 1.54 & 0.05 & 1.59 & 0.09 & 1.48 & 0.10 & 1.56 & 0.09 \\
\hline
\end{tabular}

Absence of superscript letters indicates non-significant differences between treatments $(P \geq 0.05)$.

DGI, daily growth index $=100 \times\left((\text { final body weight })^{1 / 3}-(\text { initial body weight })^{1 / 3}\right) /$ days; $F C R$, feed conversion ratio $=$ dry feed intake/weight gain; PER, protein efficiency ratio $=$ weight gain/crude protein intake.

Table 3 Voluntary feed intake $(n=3)$ and apparent digestibility coefficients $(n=2)$ in Senegalese sole fed the experimental diets for 82 days

\begin{tabular}{|c|c|c|c|c|c|c|c|c|c|c|}
\hline & \multicolumn{10}{|c|}{ Dietary treatments } \\
\hline & \multicolumn{2}{|l|}{ AP2.5 } & \multicolumn{2}{|l|}{ AP3.2 } & \multicolumn{2}{|l|}{ AP6.0 } & \multicolumn{2}{|l|}{ AP6.5 } & \multicolumn{2}{|l|}{ AP8.0 } \\
\hline & Mean & SD & Mean & SD & Mean & SD & Mean & SD & Mean & SD \\
\hline \multicolumn{11}{|c|}{ Intake (g or $\mathrm{kJ} \mathrm{kg}^{-1} \mathrm{ABW}$ day $^{-1}$ ) } \\
\hline Dry matter & 10.92 & 0.75 & 11.13 & 0.69 & 11.15 & 0.55 & 11.75 & 1.17 & 11.70 & 0.30 \\
\hline Protein & 6.13 & 0.42 & 6.18 & 0.38 & 6.27 & 0.31 & 6.42 & 0.64 & 6.56 & 0.17 \\
\hline Lipids & 1.05 & 0.07 & 1.02 & 0.06 & 0.97 & 0.03 & 1.00 & 0.10 & 0.98 & 0.03 \\
\hline Phosphorus & 0.07 & $0.00^{\mathrm{e}}$ & 0.10 & $0.01^{d}$ & 0.14 & $0.01^{\mathrm{c}}$ & 0.17 & $0.02^{\mathrm{b}}$ & 0.20 & $0.01^{a}$ \\
\hline Energy & 240.64 & 16.44 & 243.36 & 15.07 & 238.09 & 11.66 & 250.23 & 24.83 & 248.11 & 6.43 \\
\hline \multicolumn{11}{|l|}{ ADC (\%) } \\
\hline Dry matter & 58.52 & $0.30^{\mathrm{bc}}$ & 55.07 & $0.17^{c}$ & 64.02 & $0.34^{\mathrm{a}}$ & 54.94 & $2.19^{c}$ & 62.56 & $0.62^{\mathrm{ab}}$ \\
\hline Phosphorus & 38.72 & $4.22^{\mathrm{bc}}$ & 36.37 & $0.34^{c}$ & 47.22 & $0.67^{a}$ & 44.22 & $1.62^{\mathrm{abc}}$ & 45.26 & $0.48^{\mathrm{ab}}$ \\
\hline
\end{tabular}

Different superscript letters indicate significant differences $(P<0.05)$ between sole fed the experimental diets.

Nutrient intake $=$ nutrient or energy ingested/ABW/days. ABW (average body weight) $=$ (initial body weight + final body weight) $/ 2$

ADC, apparent digestibility coefficient.

sented the minimum and maximum DGI values $(0.9 \pm 0.1$ and $1.1 \pm 0.1$, respectively). Similarly, no significant differences in FCR were found between AP2.5 and AP6.5 diets ( $1.1 \pm 0.1$ and $1.2 \pm 0.1$, respectively) (Table 2). Protein efficiency ratio was also similar between groups.

\section{Voluntary feed intake and apparent digestibility coefficient}

Dry matter and energy intakes were similar between conditions, ranging between $10.9-11.8 \mathrm{~g} \mathrm{~kg}^{-1} \mathrm{ABW} \mathrm{day}^{-1}$ and 238.1-253.6 kJ kg ${ }^{-1} \mathrm{ABW} \mathrm{day}^{-1}$, respectively (Table 3). No differences in nutrient intake were obtained between groups, except for $\mathrm{P}$ intake that significantly increased from AP2.5 to AP8.0 (Table 3).

Data on ADC of dry matter and $\mathrm{P}$ are reported in Table 3. Dry matter ADC varied significantly among dietary treatments; fish fed AP6.5 and AP6.0 had the lowest $(54.9 \pm 2.2)$ and the highest $(64.0 \pm 0.3 \%)$ values, respectively. Phosphorus ADC was also significantly affected by dietary treatment, achieving the highest and lowest values in AP8.0 and AP3.2 diets, respectively.

\section{Whole-body composition. Phosphorus gain and retention}

Whole-body moisture, ash, protein and energy of Senegalese sole reared under different dietary $\mathrm{P}$ conditions were similar after 82 days of feeding $(P \geq 0.05)$ (Table 4). Significant differences in whole-body lipid and $\mathrm{P}$ contents were, in contrast, achieved between dietary treatments (Table 4). Increasing dietary $P$ levels significantly reduced whole-body lipid composition and increased the vertebrae $\mathrm{P}$ level (Table 4), with AP8.0 and AP2.5 diets presenting the high- 
Table 4 Whole-body composition, phosphorus gain and retention, and vertebrae phosphorus content in Senegalese sole fed the experimental diets for 82 days $(n=3)$

\begin{tabular}{|c|c|c|c|c|c|c|c|c|c|c|}
\hline & \multicolumn{10}{|c|}{ Dietary treatments } \\
\hline & \multicolumn{2}{|l|}{ AP2.5 } & \multicolumn{2}{|l|}{ AP3.2 } & \multicolumn{2}{|l|}{ AP6.0 } & \multicolumn{2}{|l|}{ AP6.5 } & \multicolumn{2}{|l|}{ AP8.0 } \\
\hline & Mean & SD & Mean & SD & Mean & SD & Mean & SD & Mean & SD \\
\hline \multicolumn{11}{|c|}{ Whole-body comp. ( $\mathrm{g} \mathrm{kg}^{-1} \mathrm{WW}$ or $\mathrm{kJ} \mathrm{g}^{-1} \mathrm{DM}$ ) } \\
\hline Wet weight & 745.2 & 6.8 & 746.0 & 4.7 & 750.2 & 3.9 & 748.7 & 3.2 & 747.1 & 7.9 \\
\hline Ash & 17.7 & 2.5 & 17.7 & 1.8 & 19.4 & 1.4 & 19.9 & 1.1 & 23.3 & 4.1 \\
\hline Protein & 177.8 & 9.3 & 178.1 & 4.0 & 177.0 & 4.1 & 178.1 & 5.5 & 178.6 & 4.0 \\
\hline Lipids & 61.9 & $4.3^{\mathrm{ab}}$ & 63.5 & $5.0^{\mathrm{a}}$ & 55.3 & $2.7^{\mathrm{b}}$ & 55.7 & $1.5^{\mathrm{b}}$ & 55.4 & $4.0^{\mathrm{b}}$ \\
\hline Phosphorus & 2.9 & $0.3^{\mathrm{b}}$ & 2.9 & $0.5^{\mathrm{b}}$ & 3.5 & $0.3^{\mathrm{ab}}$ & 3.6 & $0.4^{\mathrm{a}}$ & 3.5 & $0.2^{\mathrm{a}}$ \\
\hline Energy & 6.47 & 0.07 & 6.39 & 0.43 & 6.14 & 0.12 & 6.11 & 0.15 & 6.13 & 0.16 \\
\hline \multicolumn{11}{|l|}{ Gain $\left(\mathrm{g} \mathrm{kg}^{-1} \mathrm{ABW}\right.$ day $\left.^{-1}\right)$} \\
\hline Dry matter & 2.62 & 0.12 & 2.54 & 0.21 & 2.56 & 0.08 & 2.53 & 0.11 & 2.69 & 0.20 \\
\hline Phosphorus & 0.02 & $0.00^{\mathrm{b}}$ & 0.02 & $0.00^{\mathrm{b}}$ & 0.03 & $0.00^{\mathrm{ab}}$ & 0.03 & $0.00^{\mathrm{ab}}$ & 0.03 & $0.00^{\mathrm{a}}$ \\
\hline \multicolumn{11}{|l|}{ Retention (\% Intake) } \\
\hline Dry matter & 24.03 & 2.00 & 22.75 & 0.56 & 22.98 & 0.76 & 21.58 & 1.24 & 22.98 & 1.62 \\
\hline Phosphorus (on total P basis) & 26.40 & 7.71 & 18.42 & 6.60 & 21.29 & 2.85 & 17.78 & 3.54 & 15.40 & 2.01 \\
\hline Phosphorus (on available P fraction) & 67.05 & 19.59 & 49.92 & 17.89 & 44.64 & 5.98 & 39.85 & 7.93 & 34.13 & 4.47 \\
\hline \multicolumn{11}{|l|}{ Vertebrae content $\left(\mathrm{g} \mathrm{kg}^{-1} \mathrm{DM}\right)$} \\
\hline Phosphorus & 35.8 & $1.4^{b}$ & 40.8 & $4.2^{\mathrm{ab}}$ & 41.2 & $3.7^{\mathrm{ab}}$ & 44.5 & $4.9^{\mathrm{ab}}$ & 47.9 & $5.8^{\mathrm{a}}$ \\
\hline
\end{tabular}

Different superscript letters indicates significant differences between sole fed the experimental diets $(P<0.05)$.

WW, wet weight; DM, dry matter; ABW, average body weight.

est and lowest vertebrae $P$ values $(48 \pm 6$ and $36 \pm$ $1 \mathrm{~g} \mathrm{~kg}^{-1} \mathrm{DM}$, respectively).

Regression analysis performed on whole-body $\mathrm{P}$ and ash contents revealed quadratic models as the best fitting option ( $R^{2}=0.559$ and $R^{2}=0.674$, respectively) (Fig. 1a, b). In contrast to body indicators, a linear model achieved the finest fitting $\left(R^{2}=0.662\right)$ to explain the relationship between dietary and vertebrae P contents (Fig. 1c).

Phosphorus gain differed significantly $(P<0.05)$ among experimental conditions, with sole fed AP2.5 and AP3.2 diets exhibiting significantly lower values than those fed AP8.0 diet (Table 4). Phosphorus retention (considering both total and available fraction) remained, however, similar between the different dietary conditions (Table 4).

\section{Bone density and deformities analyses}

Senegalese sole fed with different dietary $\mathrm{P}$ content presented a similar bone density after 82 days (Table 5). The narrow range of values achieved in this parameter with the lowest and highest mean grey values observed in AP2.5 and AP3.2 diets (230.4 and 234.9, respectively) should be noticed.

The dietary $P$ level did not significantly influence the incidence of deformities, ranging between $37.5 \%$ and $58.3 \%$ (AP6.5 and AP2.5 diets, respectively) (Fig. 2;
Table 5). Deformity charge also was similar $(P>0.05)$ between dietary treatments (Table 5).

\section{Bone metabolism enzyme activities}

The activity of ALP and TRAP in bone homogenates is presented in Fig. 3. The groups fed the DCP-added diets showed a significant increase in ALP activity $(P<0.05)$ in comparison with fish fed the basal diet (AP2.5), with the exception of AP6.0. In contrast, the highest TRAP activity $\left(0.4 \pm 0.1 \mu \mathrm{U} \mathrm{mg}^{-1}\right.$ protein) was precisely found in fish fed the AP2.5 diet, significantly differing from sole fed all other diets.

\section{Discussion}

Increasing the dietary content of available $\mathrm{P}$ from 2.5 to $8.0 \mathrm{~g} \mathrm{~kg}^{-1}$ dry diet in plant protein-based practical diets for Senegalese sole ( $76 \%$ plant protein) had practically no effect on final body weight, daily growth index, feed conversion ratio and protein efficiency ratio. The results concerning growth performance are in agreement with previous data reported in $S$. senegalensis juveniles fed high levels of PP sources (Silva et al. 2010; Cabral et al. 2013). Specifically, the DGI of fish fed AP6.0 (with a 75\% substitution of dietary FM and available $\mathrm{P}$ content of 

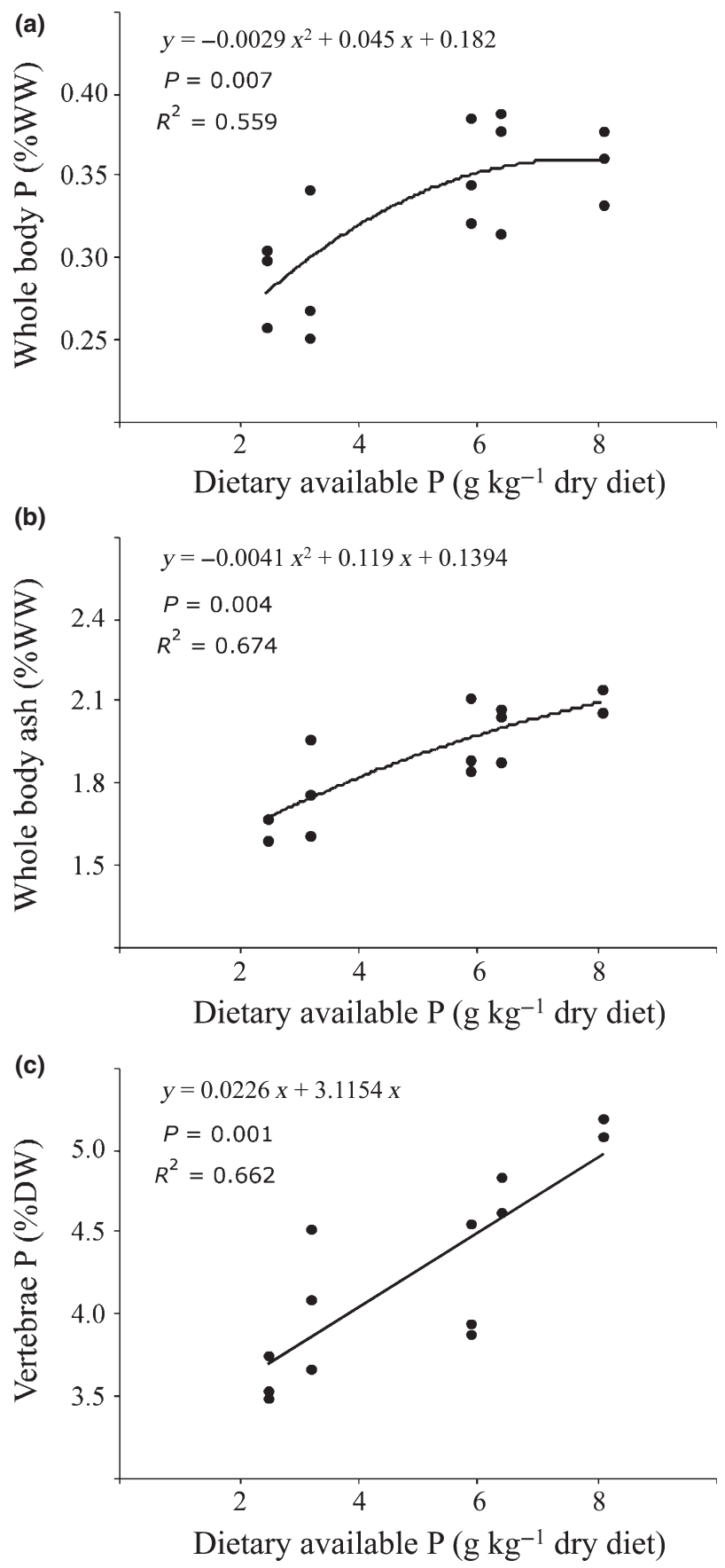

Figure 1 Regression analysis to describe the relationship between dietary available P and (a) whole-body phosphorus, (b) wholebody ash and (c) vertebrae phosphorus content. Equations, statistical $P$-values and coefficients of determination are specified for every regression.

$6.0 \mathrm{~g} \mathrm{~kg}^{-1}$ dry diet) is equivalent to that previously reported by Cabral et al. (2011) for the same PP and P inclusion level (DGI of 1.0). A recent meta-analytic study suggested that weight gain is one of the most reliable response criteria to estimate the $\mathrm{P}$ requirement of a target species (Prabhu et al. 2013). Growth performance depression associated with P-deficient diets has been extensively reported in aquaculture relevance species, allowing estimates of dietary $\mathrm{P}$ requirements. In flatfish species, a significantly lower weight gain and depressed appetite was reported in Japanese flounder juveniles fed a dietary total P level of $3.3 \mathrm{~g} \mathrm{~kg}^{-1}$ diet (Wang et al. 2005). Similarly, growth impairment was reported in several pelagic fish: dietary total $\mathrm{P}$ levels of $8.6,7.3,5.7$ and $1.5 \mathrm{~g} \mathrm{~kg}^{-1}$ diet caused a decline in the growth of Japanese sea bass, milkfish, sea bream and striped bass juveniles, respectively (Dougall et al. 1996; Borlongan \& Satoh 2001; PimentelRodrigues \& Oliva-Teles 2001; Zhang et al. 2006). Moreover, in large yellow croaker, mirror carp and black sea bream, growth impairment was reported under dietary available $\mathrm{P}$ contents of $5.5,4.2$ and $3.6 \mathrm{~g} \mathrm{~kg}^{-1}$ diet, respectively (Kim et al. 1998; Mai et al. 2006; Shao et al. 2008). In contrast, Senegalese sole juveniles showed similar growth performance with all dietary treatments (DGI 0.91.0), regardless of the dietary $P$ level. Similar weight gain and feed efficiency were also observed in Atlantic salmon $(1.4 \mathrm{~g})$ juveniles when a range of $4-25 \mathrm{~g}$ total $\mathrm{P} \mathrm{kg}^{-1}$ diet was evaluated (Åsgård \& Shearer 1997). European sea bass (Dicentrarchus labrax) juveniles (10 g) also showed equivalent growth rates when fed diets with $5-12 \mathrm{~g}$ total $\mathrm{P} \mathrm{kg}^{-1}$ levels (Oliva-Teles \& Pimentel-Rodrigues 2004). Moreover, $4.6 \mathrm{~g}$ Atlantic halibut juveniles exhibited a similar SGR and FCR when a low total P level $\left(5 \mathrm{~g} \mathrm{~kg}^{-1}\right.$ diet) was compared with a higher level $\left(12 \mathrm{~g} \mathrm{~kg}^{-1}\right.$ diet $)$ (Lewis-McCrea \& Lall 2010). Therefore, a high tolerance of S. senegalensis to grow under rearing conditions using low $\mathrm{P}$ content practical diets (as low as $2.5 \mathrm{~g}$ available $\mathrm{P} \mathrm{kg}^{-1}$ dry diet) may be inferred from the present results. If such low dietary $\mathrm{P}$ level can still sustain, growth during long-term trials requires further investigation.

Feed intake showed no differences between dietary $\mathrm{P}$ levels. All groups ingested similar dry matter, protein, lipid and energy levels. As a function of dietary DCP level, P was differentially ingested among experimental groups. No differences in VFI caused by dietary $\mathrm{P}$ content were observed in sea bass (Oliva-Teles \& Pimentel-Rodrigues 2004) and mirror carp (Kim et al. 1998) juveniles. However, Uyan et al. (2007) reported a significantly lower feed intake in Japanese flounder early juveniles when levels of 15-16 and $23-27 \mathrm{~g}$ total $\mathrm{P} \mathrm{kg}^{-1}$ diet were reduced to 6$9 \mathrm{~g}$ total $\mathrm{P} \mathrm{kg}^{-1}$ diet. Similarly, lower dietary P levels (413 and $1-11 \mathrm{~g} \mathrm{~kg}^{-1}$ diet as total and available $\mathrm{P}$ contents, respectively) reduced the VFI in gilthead sea bream ( $\mathrm{Pi}$ - 
Table 5 Bone density and deformities occurrence determined by X-ray analysis in vertebral columns of sole fed the experimental diets for 82 days $(n=3)$

\begin{tabular}{|c|c|c|c|c|c|c|c|c|c|c|}
\hline & \multicolumn{10}{|c|}{ Dietary treatments } \\
\hline & \multicolumn{2}{|l|}{ AP2.5 } & \multicolumn{2}{|l|}{ AP3.2 } & \multicolumn{2}{|l|}{ AP6.0 } & \multicolumn{2}{|l|}{ AP6.5 } & \multicolumn{2}{|l|}{ AP8.0 } \\
\hline & Mean & SD & Mean & SD & Mean & SD & Mean & SD & Mean & SD \\
\hline \multicolumn{11}{|l|}{ Bone density } \\
\hline Mean grey value & 230.41 & 1.25 & 234.92 & 4.41 & 231.52 & 4.74 & 232.11 & 4.57 & 233.40 & 2.15 \\
\hline \multicolumn{11}{|l|}{ Deformities analysis } \\
\hline Deformed fish (\%) & 58.33 & 14.43 & 37.50 & 17.68 & 50.00 & 25.00 & 37.50 & 14.43 & 50.00 & 43.30 \\
\hline Deformity charge & 1.17 & 0.29 & 1.50 & 0.50 & 1.22 & 0.38 & 1.00 & 0.00 & 1.33 & 0.47 \\
\hline
\end{tabular}

Absence of superscript letters indicates non-significant differences between dietary treatments $(P \geq 0.05)$.

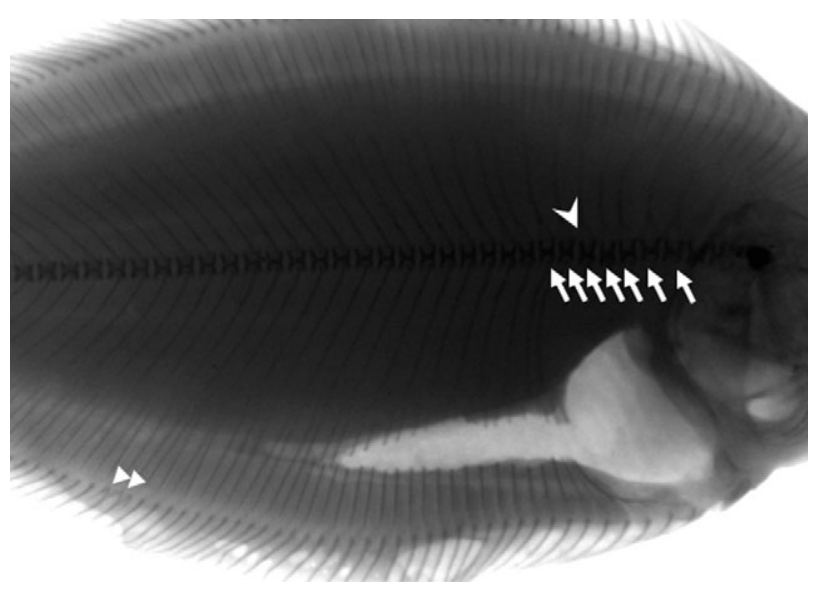

Figure 2 Deformed and compressed vertebrae in prehaemal region (arrows), with fused neural arches (large arrowhead), in Senegalese sole. Fusions in the anal fin rays are also indicated (small arrowheads).

mentel-Rodrigues \& Oliva-Teles 2001) and rainbow trout (Oncorhynchus mykiss) (Rodehutscord et al. 1995) juveniles. In the present study, Senegalese sole fed increasing $\mathrm{P}$ dietary levels exhibited a similar feed intake after a 12-week experimental period. Considering that both growth rate and FCR were similar among dietary treatments, any attempt to counteract a dietary $\mathrm{P}$ deficiency by modulating the feeding activity has to be discarded.

The ADC values of dry matter and $\mathrm{P}$ were significantly affected by experimental treatments. The highest dry matter $(64.0 \pm 0.3 \%)$ and $\mathrm{P}(47.2 \pm 0.7 \%)$ ADC values were observed in fish fed AP6.0 diet. Notwithstanding the present work applied the only reported procedure to collect faeces from $30 \mathrm{~g}$ sole (Cabral et al. 2011, 2013; Borges et al. 2013), a special caution must be considered to deal with digestibility data in this species. In general, such results are in agreement with those obtained by Cabral

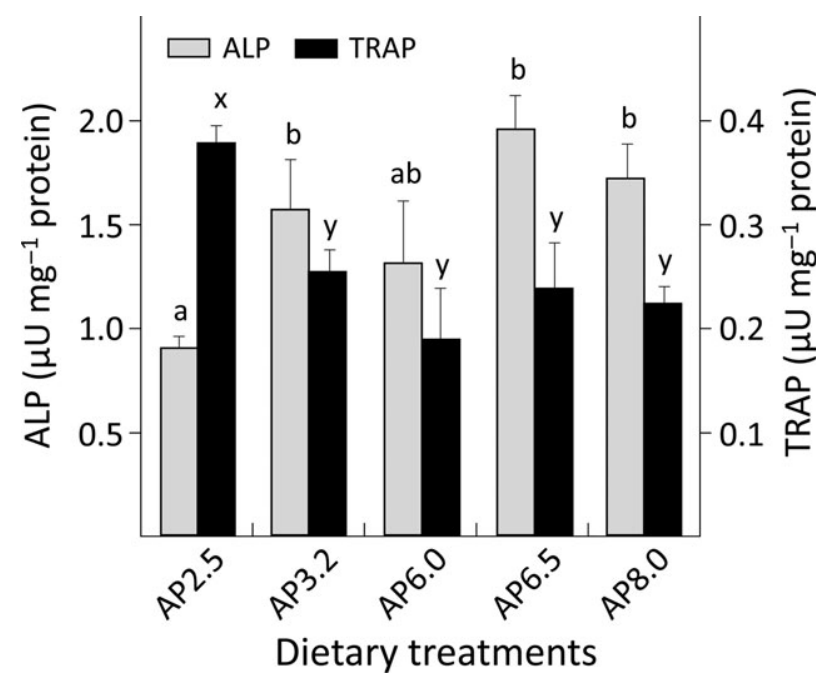

Figure 3 Alkaline phosphatase (ALP) and tartrate-resistant acid phosphate (TRAP) activities (mean value $\pm \mathrm{SD}, n=3$ ) measured in vertebral bone samples of sole fed the experimental diets for 82 days. Different letters indicate significant differences concerning $\operatorname{ALP}(\mathrm{a}, \mathrm{b}, \mathrm{c})$ and TRAP $(\mathrm{x}, \mathrm{y}, \mathrm{z})$ activities $(P<0.05)$.

et al. (2011) in Senegalese sole juveniles also fed a 75\% PP diet and a similar dietary $\mathrm{P}$ content. A mixed effect caused by the target species and the raw materials contained in the tested diet explains the different ADC of $\mathrm{P}$ previously reported in fish juveniles fed basal diets (no P supplementation): Atlantic salmon early specimens fed semipurified diet (casein-gelatine) showed an apparent $\mathrm{P}$ absorption of 89.0\% (Åsgård \& Shearer 1997); this value declined to $50.0 \%$ in Japanese sea bass and large yellow croacker juveniles fed practical diets based in fishmeal and soybean meal, respectively (Mai et al. 2006; Zhang et al. 2006). In the present study, Senegalese sole fed the basal diet exhibited an even lower ADC of P (38.7\%). This ADC value is very similar $(37.0 \%)$ to that reported in black sea bream 
fed semipurified diet (casein-dextrine) (Shao et al. 2008) and even higher than that reported in mirror carp juveniles $(20.0 \%)$ fed a practical diet using wheat meal (Kim et al. 1998). Interestingly, the mineral $P$ supplementation in our basal diet (AP2.5), reaching dietary available $\mathrm{P}$ contents above $6.0 \mathrm{~g} \mathrm{~kg}^{-1}$ dry diet (AP6.5 and AP8.0 diets), did not increase the corresponding $\mathrm{P}$ digestibility values. A limited ability of Senegalese sole to absorb $\mathrm{P}$ from mineral sources (DCP in the present work) is thus suggested. In this regard, the potentially accumulated orthophosphate in the recirculating aquaculture system might be considered as a possible alternative source of available P for fish. Although a certain orthophosphate uptake from rearing water has been suggested in certain marine species (Van Bussel et al. 2013), a direct demonstration of such fact has not been reported to date. Additional studies are hence required.

Increasing the dietary $P$ levels significantly modified the body lipid and $\mathrm{P}$ composition of Senegalese sole. Body lipid, $\mathrm{P}$ and ash contents obtained in the present study were similar to those previously reported in sole juveniles fed a $75 \%$ PP diet with similar dietary total P level (Cabral et al. 2011). Increased whole-body lipid content associated with P-deficient diets has been quite commonly observed in other fish species (Rodehutscord et al. 1995; Roy \& Lall 2003; Zhang et al. 2006; Uyan et al. 2007). Altered oxidative phosphorylation and subsequent inhibition of tricarboxylic acid cycle have been pointed out as the responsible underlying mechanism of such increased lipid level (Skonberg et al. 1997; Shao et al. 2008). In fact, Senegalese sole fed the lowest P level diets (AP2.5 and AP3.2) exhibited the highest body lipid contents, suggesting a metabolic impairment. Moreover, the body mineralization - evaluated through whole-body $\mathrm{P}$ and ash levels - is often correlated with dietary $\mathrm{P}$ content to evaluate a species $\mathrm{P}$ requirement. Following this procedure, dietary available $\mathrm{P}$ requirements of 5.6, 8.1, 8.6 and $11.0 \mathrm{~g} \mathrm{~kg}^{-1}$ diet have been determined in rainbow trout, black sea bream, Japanese sea bass and Atlantic salmon juveniles, respectively (Rodehutscord et al. 1995; Åsgård \& Shearer 1997; Zhang et al. 2006; Shao et al. 2008). Regression analysis performed on whole-body $\mathrm{P}$ and ash contents revealed quadratic models as the best fitting option, with 7.8 and $14.5 \mathrm{~g}$ available $\mathrm{P} \mathrm{kg}^{-1}$ dry diet inducing maximum responses, respectively. In terms of dietary requirement, both values are very distant from the one inferred from the growth trial (below $2.5 \mathrm{~g}$ available $\mathrm{P} \mathrm{kg}^{-1}$ dry diet). These results show that Senegalese sole growth performance remains unaffected with much lower dietary $\mathrm{P}$ contents than those needed to induce maximal body mineralization.
Phosphorus level contained in vertebrae of sole was positively and linearly related to dietary $\mathrm{P}$ content. Vertebrae density - an indicator of bone mineralization status - and occurrence of deformities did not differ among experimental diets. Previous studies on $\mathrm{P}$ requirement in pelagic species juveniles have reported high values of vertebrae $\mathrm{P}$ in silver perch (111 $\left.\mathrm{g} \mathrm{kg}^{-1} \mathrm{DM}\right)$ (Yang et al. 2006) and black sea bream (106 $\mathrm{g} \mathrm{kg}^{-1}$ DM) (Shao et al. 2008). Vertebrae $\mathrm{P}$ levels of $70-82 \mathrm{~g} \mathrm{~kg}^{-1}$ DM were observed in Japanese sea bass (Zhang et al. 2006), large yellow croaker (Mai et al. 2006) and milkfish (Borlongan \& Satoh 2001), whereas in striped bass, a lower value $\left(62 \mathrm{~g} \mathrm{~kg}^{-1} \mathrm{DM}\right)$ was reported (Dougall et al. 1996). In opposition to these reports that reached a plateau in their dose-response approaches, a linear relationship was observed both in haddock and channel catfish (Ictalurus punctatus) juveniles: vertebrae $\mathrm{P}$ levels increased from 101 to $126 \mathrm{~g} \mathrm{~kg}^{-1} \mathrm{DM}$ and from 68 to $93 \mathrm{~g} \mathrm{~kg}^{-1} \mathrm{DM}$ under 4-12 and 2-6 $\mathrm{g}$ available $\mathrm{P} \mathrm{kg}^{-1}$ diet conditions, respectively (Eya \& Lovell 1997; Roy \& Lall 2003). Atlantic halibut juveniles ( $4.6 \mathrm{~g})$ increased their vertebrae $\mathrm{P}$ content from 92 to $115 \mathrm{~g} \mathrm{~kg}^{-1} \mathrm{DM}$ when dietary total $\mathrm{P}$ content varied from 5 to $12 \mathrm{~g} \mathrm{~kg}^{-1}$ diet, after 14 weeks of feeding (Lewis-McCrea \& Lall 2010). In the present study, Senegalese sole linearly increased the P level contained in their vertebrae (from 36 to $48 \mathrm{~g} \mathrm{~kg}^{-1} \mathrm{DM}$ ), although with a noticeably lower range of values compared to those described for other species. Notwithstanding the different vertebrae $\mathrm{P}$ content, similar bone density and deformities occurrence was observed in all experimental treatments. Moreover, results concerning bone metabolism enzymes showed a marked difference between osteoblastic-osteoclastic activity (Witten 1997) in AP2.5 diet (2.5 g available $\mathrm{P} \mathrm{kg}^{-1}$ dry diet) and the remaining dietary treatments. Enhanced activity of TRAP - secreted by osteoclasts during bone resorption - concomitant with the lowest ALP activity, representative of osteoblastic activity essential for bone calcification, in fish fed the lowest dietary $\mathrm{P}$ level suggests an altered status of bone formation-resorption processes under such dietary $\mathrm{P}$ treatment. To the best of our knowledge, the present study is the first to report vertebrae $\mathrm{P}$ levels in $S$. senegalensis growth juveniles. Whether the low mineralization found in the vertebrae of sole is a common trait in this species or, in contrast, was caused by dietary $\mathrm{P}$ conditions (via bone $\mathrm{P}$ mobilization) is unclear and requires further research.

In conclusion, increasing the dietary available $\mathrm{P}$ content up to $8.0 \mathrm{~g} \mathrm{~kg}^{-1}$ dry diet did not influence growth parameters, feed intake and vertebrae deformities occurrence in Senegalese sole juveniles. Dietary $\mathrm{P}$ conditions did affect the body lipid and $\mathrm{P}$ contents after a 12-week period. 
Vertebrae phosphorus level in sole was low in comparison with other marine fish species and linearly affected by the dietary level of P. Overall results indicate a high tolerance of Senegalese sole to low dietary $\mathrm{P}$ content, raising the possibility to feed this species with high plant protein content practical diets (up to $75 \%$ substituted FM by PP). Detailed investigations assessing the bone mineralization process and subsequent vertebral $\mathrm{P}$ mobilization are recommended in Senegalese sole.

\section{Acknowledgements}

This work was partially supported by NORTE-07-0124FEDER-000038, in the context of the North Region Operational Programme (ON.2 - O Novo Norte), under the project Sustainable Aquaculture and Animal Welfare (AQUAIMPROV). There are no conflict of interests in connection with the present study.

\section{References}

AOAC (2006) Official Methods of Analysis of AOAC International. AOAC International, Gaithersburg, MD.

Åsgård, T. \& Shearer, K.D. (1997) Dietary phosphorus requirement of juvenile Atlantic salmon, Salmo salar L. Aquacult. Nutr., 3, 17-23.

Bessey, O.A., Lowry, O.H. \& Brock, M.J. (1946) A method for the rapid determination of alkaline phosphatase with five cubic millimetres of serum. J. Biol. Chem., 164, 321-329.

Bolin, D.W., King, R.P. \& Klosterman, E.W. (1952) A simplified method for the determination of chromic oxide $\left(\mathrm{Cr}_{2} \mathrm{O}_{3}\right)$ when used as an index substance. Science, 116, 634-635.

Borges, P., Oliveira, B., Casal, S., Dias, J., Conceição, L. \& Valente, L.M.P. (2009) Dietary lipid level affects growth performance and nutrient utilisation of Senegalese sole (Solea senegalensis) juveniles. Br. J. Nutr., 102, 1007-1014.

Borges, P., Medale, F., Veron, V., Pires, Md.A., Dias, J. \& Valente, L.M.P. (2013) Lipid digestión, absorption and uptake in Solea senegalensis. Comp. Biochem. Physiol. A, 166, 26-35.

Borlongan, I.G. \& Satoh, S. (2001) Dietary phosphorus requirement of juvenile milkfish, Chanos chanos (Forsskal). Aquacult. Res., 32(Suppl. 1), 26-32.

Bradford, M.M. (1976) A rapid sensitive method for the quantitation of microgram quantities of protein utilizing the principle of protein-dye binding. Anal. Biochem., 72, 248-254.

Cabral, E.M., Bacelar, M., Batista, S., Castro-Cunha, M., Ozório, R.O.A. \& Valente, L.M.P. (2011) Replacement of fishmeal by increasing levels of plant protein blends in diets for Senegalese sole (Solea senegalensis) juveniles. Aquaculture, 322-323, 74-81.

Cabral, E.M., Fernandes, T.J.R., Campos, S.D., Castro-Cunha, M., Oliveira, M.B.P.P., Cunha, L.M. \& Valente, L.M.P. (2013) Replacement of fishmeal by plant protein sources up to $75 \%$ induces good growth performance without affecting flesh quality in ongrowing Senegalese sole. Aquaculture, 380-383, 130-138.

Dias, J., Conceicao, L.E.C., Ramalho Ribeiro, A., Borges, P., Valente, L.M.P. \& Dinis, M.T. (2009) Practical diet with low fish-derived protein is able to sustain growth performance in gilthead seabream (Sparus aurata) during the grow-out phase. Aquaculture, 293, 255-262.

Dias, J., Yúfera, M., Valente, L.M.P. \& Rema, P. (2010) Feed transit and apparent protein, phosphorus and energy digestiblity of practical feed ingredients by Senegalese sole (Solea senegalensis). Aquaculture, 302, 94-99.

Dionísio, G., Campos, C., Valente, L.M.P., Conceição, L.E.C., Cancela, M.L. \& Gavaia, P.J. (2012) Effect of egg incubation temperature on the occurrence of skeletal deformities in Solea senegalensis. J. Appl. Ichthyol., 28, 471-476.

Dougall, D.S., Woods, L.C. III, Douglass, L.W. \& Soares, J.H. (1996) Dietary phosphorus requirement of juvenile striped bass Morone saxatilis. J. World. Aquacult. Soc., 27, 82-91.

Eya, J.C. \& Lovell, R.T. (1997) Available phosphorus requirements of food-size channel catfish (Ictalurus punctatus) fed practical diets in ponds. Aquaculture, 154, 283-291.

FAO (2011) World Aquaculture 2010. FAO, Fisheries and Aquaculture Technical Paper. FAO, Roma, 120 pp.

Gatlin, D.B. III, Barrows, F.T., Brown, P. et al. (2007) Expanding the utilization of sustainable plant products in aquafeeds: a review. Aquacult. Res., 38, 551-579.

Goto, A. \& Tsukamoto, I. (2003) Increase in tartrate-resistant acid phosphatase of bone at the early stage of ascorbic acid deficiency in the ascorbate-requiring osteogenic disorder shionogi (ODS) rat. Calcif. Tissue Int., 73, 180-185.

Kaushik, S.J. (2001) Mineral nutrition. In: Nutrition and Feeding of Fish and Crustaceans (Guillaume, J., Kaushik, S.J., Bergot, P. \& Métailler, R. eds), pp. 169-181. Praxis Publishing, Chichester, UK.

Kaushik, S.J., Covès, D., Dutto, G. \& Blanc, D. (2004) Almost total replacement of fish meal by plant protein sources in the diet of a marine teleost, the European seabass, Dicentrarchus labrax. Aquaculture, 230, 391-404.

Kim, J.D., Kim, K.S., Song, J.S., Lee, J.Y. \& Jeong, K.S. (1998) Optimum level of dietary monocalcium phosphate based on growth and phosphorus excretion of mirror carp, Cyprinus carpio. Aquaculture, 161, 337-344.

Lall, S.P. (2002) The minerals. In: Fish Nutrition, 3rd edn (Halver, J.E. \& Hardy, R.W. eds), pp. 259-308. Academic Press, London, UK.

Lall, S.P. \& Lewis-McCrea, L.M. (2007) Role of nutrients in skeletal metabolism and pathology in fish - An overview. Aquaculture, 267, 3-19.

Lewis-McCrea, L.M. \& Lall, S.P. (2010) Effects of phosphorus and vitamin $\mathrm{C}$ deficiency, vitamin A toxicity, and lipid peroxidation on skeletal abnormalities in Atlantic halibut (Hippoglossus hippoglossus). J. Appl. Ichthyol., 26, 334-343.

Liu, H., Peng, H., Wu, Y. et al. (2013) The promotion of bone regeneration by nanofibrous hydroxyapatite/chitosan scaffolds by effects on integrin-BMP/Smad signaling pathway in BMSCs. Biomaterials, 34, 4404-4417.

Lund, I., Dalsgaard, J., Tolderlund-Rasmussen, H., Holm, J. \& Jokumsen, A. (2011) Replacement of fish meal with a matrix of organic plant proteins in organic trout (Oncorhynchus mykiss) feed, and the effects on nutrient utilization and fish performance. Aquaculture, 321, 259-266.

Mai, K., Zhang, C., Ai, Q., Duan, Q., Xu, W., Zhang, L., Luifu, Z. \& Tan, B. (2006) Dietary phosphorus requirement of large yellow croaker, Pseudosciaena crocea R. Aquaculture, 251, 346353.

Maynard, L.A., Loosli, J.K., Hintz, H.F. \& Warner, R.G. (1979) Animal Nutrition, 7th edn. Mc-Graw-Hill, New York, $603 \mathrm{pp}$. 
Morais, S., Aragao, C., Cabrita, E. et al. (2014) New developments and biological insights into the farming of Solea senegalensis reinforcing its aquaculture potential. Rev. Aquacult., 6, 1-37.

Murphy, J. \& Riley, J.P. (1962) A modified single solution method for the determination of phosphate in natural waters. Anal. Chim. Acta, 27, 31-36.

National Research Council (NRC) (2011) 8. Minerals. In: Nutrients Requirements of Fish and Shrimp (National Research Council of the National Academies eds), pp. 163-185. The National Academies Press, Washington, DC, USA.

Oliva-Teles, A. \& Pimentel-Rodrigues, A. (2004) Phosphorus requirement of European sea bass (Dicentrarchus labrax) juveniles. Aquacult. Res., 35, 636-642.

Pimentel-Rodrigues, A. \& Oliva-Teles, A. (2001) Phosphorus requirements of gilthead sea bream (Sparus aurata L.) juveniles. Aquacult. Res., 32(Suppl. 1), 157-161.

Prabhu, P.A.J., Schrama, J.W. \& Kaushik, S.J. (2013) Quantifying dietary phosphorus requirement of fish - a meta-analytic approach. Aquacult. Nutr., 19, 233-249.

Pratoomyot, J., Bendiksen, E.Å., Bell, J.G. \& Tocher, D.R. (2010) Effects of increasing replacement of dietary fishmeal with plant protein sources on growth performance and body lipid composition of Atlantic salmon (Salmo salar L.). Aquaculture, 305, 124-132.

Reis, P.A. \& Almeida, C.M.R. (2008) Matrix importance in animal material pre-treatment for metal determination. Food Chem., 107, 1294-1299.

Rodehutscord, M., Pfeffer, E. \& Cowey, C.B. (1995) Requirement for phosphorus in rainbow trout (Oncorhynchus mykiss) growing from 50 to 200 g. Water Sci. Technol., 31, 137-141.

Roy, P.K. \& Lall, S.P. (2003) Dietary phosphorus requirement of juvenile haddock (Melanogrammus aeglefinus L.). Aquaculture, 221, 451-468.

Sajjadi, M. \& Carter, C.G. (2004) Dietary phytase supplementation and the utilisation of phosphorus by Atlantic salmon (Salmo salar L.) fed a canola-meal-based diet. Aquaculture, 240, 417-431.

Shao, Q., Ma, J., Xu, Z., Hu, W., Xu, J. \& Xie, S. (2008) Dietary phosphorus requirement of juvenile black seabream, Sparus macrocephalus. Aquaculture, 277, 92-100.

Silva, J.M.G., Espe, M., Conceição, L.E.C., Dias, J. \& Valente, L.M.P. (2009) Senegalese sole juveniles (Solea senegalensis Kaup, 1858) grow equally well on diets devoid of fish meal provided the dietary amino acids are balanced. Aquaculture, 296, 309-317.

Silva, J.M.G., Espe, M., Conceição, J.E.C., Dias, J., Costas, B. \& Valente, L.M.P. (2010) Feed intake and growth performance of
Senegalese sole (Solea senegalensis Kaup, 1858) fed diets with partial replacement of fish meal with plant proteins. Aquacult. Res., 41, e20-e30.

Skonberg, D.E., Yogev, L., Hardy, R.W. \& Dong, F.M. (1997) Metabolic response to dietary phosphorus intake in rainbow trout (Oncorhynchus mykiss). Aquaculture, 157, 11-24.

Sugiura, S.H., Hardy, R.W. \& Roberts, R.J. (2004) The pathology of phosphorus deficiency in fish - a review. J. Fish Dis., 27, 255265.

Tacon, A.G.J. \& Metian, M. (2008) Global overview on the use of fish meal and fish oil in industrially compounded aquafeeds: Trends and future prospects. Aquaculture, 285, 146-158.

Uyan, O., Koshio, S., Ishikawa, M., Uyan, S., Ren, T., Yokoyama, S., Komilus, C.F. \& Michael, R.R. (2007) Effects of dietary phosphorus and phospholipid level on growth, and phosphorus deficiency signs in juvenile Japanese flounder, Paralichthys olivaceus. Aquaculture, 267, 44-54.

Valente, L.M.P., Linares, F., Villanueva, J.L.R. et al. (2011) Dietary protein source or energy levels have no major impact on growth performance, nutrient utilisation or flesh fatty acids composition of market-sized Senegalese sole. Aquaculture, 318, 128-137.

Van Bussel, C.G.J., Mahlmann, J., Kroeckel, S., Schroeder, J.P. \& Schulz, C. (2013) The effect of high ortho-phosphate water levels on growth, feed intake, nutrient utilization and health status of juvenile turbot (Psetta maxima) reared in intensive recirculating aquaculture systems (RAS). Aquacult. Eng., 57, 63-70.

Wang, X., Choi, S., Park, S., Yoo, G., Kim, K., Kang, J.-C. \& Bai, S. (2005) Optimum dietary phosphorus level of juvenile Japanese flounder Paralichthys olivaceus reared in the recirculating system. Fish. Sci., 71, 168-173.

Witten, P.E. (1997) Enzyme histochemical characteristics of osteoblasts and mononucleated osteoclasts in a teleost fish with acellular bone (Oreochromis niloticus, Cichlidae). Cell Tissue Res., 287, 591-599.

Yang, S.D., Lin, T.S., Liu, F.G. \& Liou, C.H. (2006) Influence of dietary phosphorus levels on growth, metabolic response and body composition of juvenile silver perch (Bidyanus bidyanus). Aquaculture, 253, 592-601.

Zar, J.H. (1999) Biostatistical Analysis. Prentice Hall, London.

Zhang, C., Mai, K., Ai, Q., Zhang, W., Duan, Q., Tan, B., Ma, H., Xu, W., Liufu, Z. \& Wang, X. (2006) Dietary phosphorus requirement of juvenile Japanese seabass, Lateolabrax japonicus. Aquaculture, 255, 201-209. 